\title{
Pinostrobin - An Anti-Leukemic Flavonoid from Polygonum lapathifolium L. ssp. nodosum (Pers.) Dans
}

\author{
Helena D. Smolarz ${ }^{\mathrm{a}, *}$, Ewaryst Mendyk ${ }^{\mathrm{b}}$, Anna Bogucka-Kocka ${ }^{\mathrm{a}}$, \\ and Janusz Kockic \\ a Chief and Department of Pharmaceutical Botany, Medical University of Lublin, \\ 1 Chodżki Str., 20-093 Lublin, Poland. E-mail: smolarz@am.lublin.pl \\ b Department of Chemistry, Analytical Laboratory, UMCS, M. Curie-Skłodowska Sq., \\ Lublin, Poland \\ c Department of Medical Genetics, Medical University of Lublin, Lublin, Poland \\ * Author for correspondence and reprint requests \\ Z. Naturforsch. 61 c, 64-68 (2006); received July 22/August 22, 2005
}

Aim of study: Search for plant compounds possessing anti-leukemic properties.

Results: We have shown that 5-hydroxy-7-methoxy flavanone (pinostrobin) isolated from Polygonum lapathifolium ssp. nodosum quickly penetrates through cytoplasm to the cellular nucleus of the cultured cells, and gives intensive apoptotic response in stimulating leukemic cells in vitro. The number of apoptotic cells increased with the concentration of pinostrobin: $10 \mathrm{~nm}-25 \%$ and $60 \% ; 100 \mathrm{~nm}-45 \%$ and $76 \% ; 1 \mu \mathrm{M}-70 \%$ and $88 \%$ for Jurkat and HL60 cell lines, respectively.

Conclusion: Pinostrobin may be considered as a good candidate for a leukemia chemopreventic agent.

Key words: Pinostrobin, Polygonum lapathifolium ssp. nodosum, Anti-Leukemic Activity

\section{Introduction}

Several flavonoids isolated from plants have been shown to have antiviral, antioxidant, antimutagenic and anticarcinogenic activities (Meragelman et al., 2001; Kerry and Rice-Evans, 1999; Zava and Duwe, 1997). Pinostrobin (5-hydroxy-7methoxy flavanone) showed weak trypanocidal (against protozoan Trypanosoma cruzi) activity (Takeara et al., 2003) and lipid antioxidant activity (Rapta et al., 1995). This natural flavanone was tested on cell cultures of human mammary carcinoma (Sukardiman et al., 2000) and human breast cancer cell line MCF-7 (Mata et al., 1997) for its cytotoxicity. The study on the influence of pinostrobin on estrogen metabolism and estrogen receptor transactivation showed that pinostrobin presents different characteristics of an ideal antihuman breast cancer compound. This compound presented an anti-aromatase activity, but also decreased DHEAS- or E2-stimulated cell proliferation and did not bind to the estrogen receptors (Le Bail et al., 2000).

Pinostrobin has been isolated from natural sources (Harborne, 1999), but till now has not been shown in plants of Polygonaceae. We examined the influence of pinostrobin isolated from Polygo- num lapathifolium L. ssp. nodosum (Pers.) Dans on the induction of apoptosis in human leukemic cells in vitro.

\section{Experimental}

\section{Plant material}

Polygonum lapathifolium ssp. nodosum was collected near Lublin, Poland in July 2004. A voucher specimen is deposited at the Chief and Department of Pharmaceutical Botany, Medical University, Lublin, Poland.

\section{Instruments}

The structure of compound $\mathbf{1}$ was established on the basis of its spectral data, using DEPT, H,H COSY, HMQC and HMBC experiments in combination with ${ }^{1} \mathrm{H}$ NMR and ${ }^{13} \mathrm{C}$ NMR spectra. NMR spectra were collected at room temperature using a NMR Bruker Avance $300 \mathrm{MHz}$ spectrometer equipped with a $5 \mathrm{~mm}$ multinuclear inverse probehead with $z$-shielded gradient. TMS was used as an internal standard. IR spectra were recorded on a Perkin-Elmer 1275X FTIR spectrometer. EI-MS spectra were obtained on a Trace DSQ Thermo Finnigan mass spectrometer. 
Cell cultures were observed using a BX41 Olympus light/fluorescence microscope. Data were processed according to the Multi Scan software.

\section{Isolation of pinostrobin}

Air-dried and powdered herb of Polygonum lapathifolium ssp. nodosum (1920 g) was extracted for $50 \mathrm{~h}$ with petroleum ether in a Soxhlet apparatus. The extract was concentrated to small volume and subjected to CC over silica gel 60 (Merck). The column was eluted using a gradient of hexane/ chloroform (1:0, 4:1, 2:1, 1:1, 1:2, 1:4, 0:1) to afford 113 fractions. Fractions $72-82(5 \mathrm{~g})$ were further chromatographed on florisil (Fluka) with chloroform/methanol mixtures $(9: 1,8: 2,7.5: 2.5,7: 3$, 6.5:3.5, 6:4, 1:1 v/v). Eluates 102-124 were separated on silica gel 60 (CC) with chloroform/methanol $(2: 8 \mathrm{v} / \mathrm{v})$. Fractions $6-18$ containing the isolated compound were finally furnished with methanol on a Sephadex LH 20 column to yield (75 mg) pure compound $\mathbf{1}$.

\section{Cell culture}

Leukemic cells (Jurkat or HL60 cell line) were incubated at the concentration of $5 \times 10$ cells $/ \mathrm{mL}$ in $5 \% \mathrm{CO}_{2}$ atmosphere for $24 \mathrm{~h}$ at $37^{\circ} \mathrm{C}$. An RPMI 1640 medium (Sigma, St. Louis, USA) with $15 \%$ fetal bovine serum (Sigma), $2 \mathrm{~mm}$ L-glutamine and antibiotics $[100 \mathrm{U} / \mathrm{mL}$ penicillin, $100 \mu \mathrm{M} /$ $\mathrm{mL}$ streptomycin and $2.5 \mu \mathrm{g} / \mathrm{mL}$ amphotericin B (Gibco, Carlsbad, USA)] served as a growing medium. The cells were stimulated with pinostrobin in following concentrations: $1 \mathrm{~nm}, 10 \mathrm{~nm}, 100 \mathrm{~nm}$, $1 \mu \mathrm{M}$ or $10 \mu \mathrm{M}$. Unstimulated cells were used as the controls. All tests were performed twice.

\section{Apoptotic test - annexin-V-Fluos assay}

The annexin-V-Fluos assay (Pharmingen) was used to estimate the number of cells in the early stage of apoptosis. The 24 -h cell cultures were centrifuged at $600 \times g$ for $10 \mathrm{~min}$, then incubated for $5 \mathrm{~min}$ in the buffer comprising $10 \mathrm{~mm}$ Hepes [ $\mathrm{N}$ (2-hydroxyethyl) piperazine- $N^{\prime}$-(2-ethanesulfonic acid) hemisodium salt] $/ \mathrm{NaOH}, \mathrm{pH} 7.4,140 \mathrm{~mm}$ $\mathrm{NaCl}, 2.5 \mathrm{~mm} \mathrm{CaCl}_{2}$, annexin $\mathrm{V}$ labeled with $0.65 \mu \mathrm{g} / \mathrm{mL}$ of FITC and propidium iodide at the concentration of $12 \mu \mathrm{g} / \mathrm{mL}$. Thereafter, samples were analysed by an Olympus BX41 light and fluorescence microscope for the presence of:
- viable cells - annexin V negative, PI negative;

- early apoptotic cells - annexin V positive, PI negative;

- late apoptotic/secondary necrotic - annexin V positive, PI positive.

The amount of apoptotic cells/sample was determined as the percentage of annexine $\mathrm{V}$ positive cells per sample.

Cell morphology was examined using a BX41 Olympus fluorescence microscope. Data were processed according to the Multi Scan software.

\section{Results}

\section{Structure elucidation of pinostrobin}

The IR spectrum had bands for phenol at $3277 \mathrm{~cm}^{-1}$ and a C-O stretching band at $1206 \mathrm{~cm}^{-1}$ which suggested that compound 1 was phenolic. A strong absorption band at $1638 \mathrm{~cm}^{-1}$ was characteristic for a conjugated carbonyl group with intermolecular hydrogen bonding.

From ${ }^{1} \mathrm{H}$ NMR spectra it is concluded that two aromatic rings are found in the structure of compound 1. Only one methoxy and one phenolic $\mathrm{OH}$ group were evident in both ${ }^{1} \mathrm{H}$ and ${ }^{13} \mathrm{C}$ NMR spectra. The methoxy group (7-OMe) at $\delta 3.81$ and the hydrogen bonded hydroxy group $(5-\mathrm{OH})$ at $\delta 12.10$ are attached to phenyl ring $\mathrm{A}$ while the second one B is not substituted. The aromatic multiplets at $\delta 7.37-7.48$ and at $\delta 7.53-7.56$ are integrated in a 3:2 ratio.

The unsubstituted nature of the $\mathrm{B}$ ring was readily apparent from the mass fragmentation pattern in the EI-MS spectrum. The MS spectrum of compound $\mathbf{1}$ showed the molecular ion $\left[\mathbf{M}^{+}\right]$at $\mathrm{m} / z$ 270 corresponding to the molecular formula $\mathrm{C}_{18} \mathrm{H}_{14} \mathrm{O}_{4}$. The appearance of two prominent peaks at $m / z 193\left[\mathrm{M}-\mathrm{C}_{6} \mathrm{H}_{5}\right]^{+}$and $m / z 166[\mathrm{M}-$ $\left.\mathrm{C}_{6} \mathrm{H}_{5}-\mathrm{C}_{2} \mathrm{H}_{3}\right]^{+}$corresponded to the loss of phenyl and styrene fragments from the molecular ion. It was further indicated that all substituents were placed at the A ring.

The methoxy and hydroxy group are separated by two protons which are visible as two doublets (H-6, H-8) at $\delta 6.10$ and $\delta 6.15$, respectively (Table I). Furthermore the pattern in the aliphatic region exhibits two geminal protons $\left(\mathrm{H}-3_{\mathrm{ax}}, \mathrm{H}-3_{\mathrm{eq}}\right)$ at $\delta 6.15$ coupled with one aliphatic proton, probably in the heterocyclic AMX ring system. The large value of $J_{2,3 \mathrm{ax}}$ suggests that proton $\mathrm{H}-2$ is axial and the neighbouring phenyl group is equatorial. These spectral data are characteristic for 


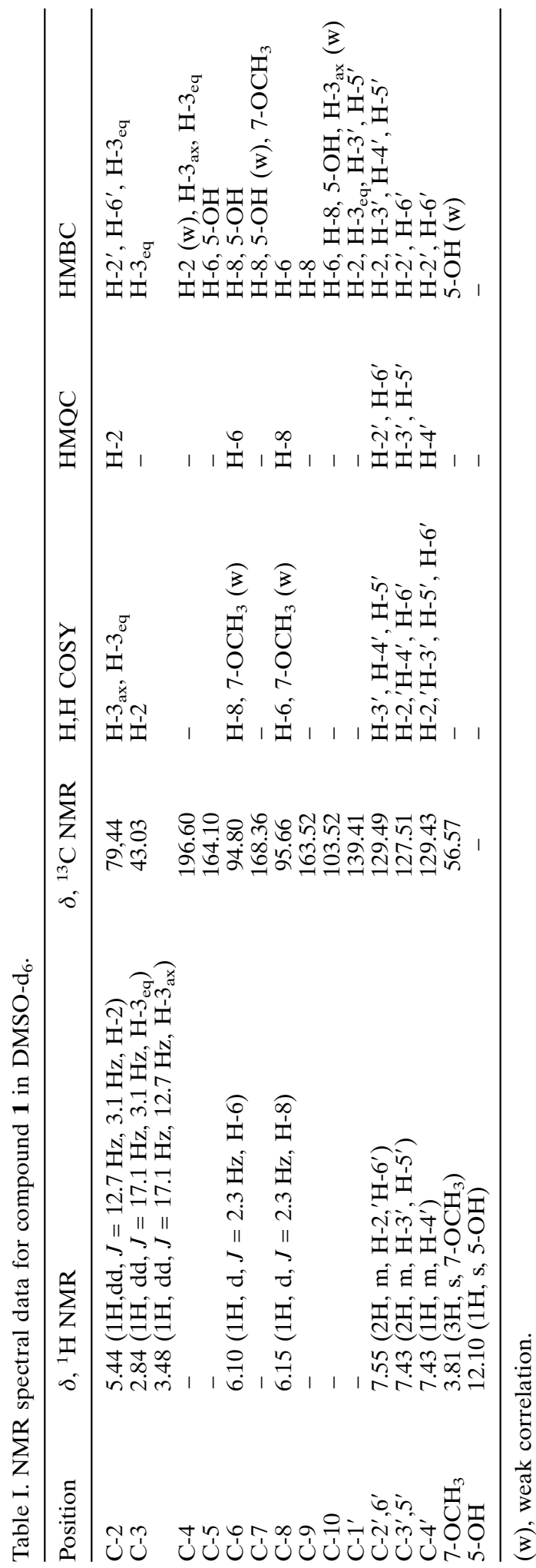

chelated 5-OH flavones and flavanones (Cuong et al., 1996).

More information can be obtained from the analysis of ${ }^{13} \mathrm{C}$ NMR spectra. The ${ }^{13} \mathrm{C}$ NMR spectrum provided fourteen signals which were divided by DEPT into eight tertiary, six quaternary, one secondary and one primary carbon atoms. Consistent with ${ }^{1} \mathrm{H}$ NMR spectral analysis, the ${ }^{13} \mathrm{C}$ NMR spectrum of $\mathbf{1}$ also displayed oxygenated methylene and methine groups at $\delta 43.03$ (C-3) and $\delta 79.44$ (C-2), a methoxy group at $\delta 56.57$ (7-OMe) and a conjugated ketone (C-4) resonating at $\delta 196.60$ (Table I). These spectral data confirmed that compound $\mathbf{1}$ was a flavanone with an unsubstituted B ring (Kuroyanagi and Fukusthima, 1982). The correlation found in COSY, HMQC and $\mathrm{HMBC}$ spectra linked all the connections in the structure of $\mathbf{1}$. The location of the methoxy group at C-7 was assigned on the basis of the observed HMBC correlation from $\delta 3.81\left(7-\mathrm{OCH}_{3}\right)$ to $\delta 168.36(\mathrm{C}-7)$ and COSY weak correlation from $\delta 3.81$ to $\delta 6.10(\mathrm{H}-6)$ and $\delta 6.15(\mathrm{H}-8)$. In the same way the location of the hydroxy group at C-5 was confirmed (Table I). The second clue necessary for the structure assignment came from the carbon resonating at $\delta 79.44$ which was assigned as $\mathrm{C}-2$ and its corresponding proton at $\delta$ $5.44(\mathrm{H}-2)$ showed correlation with the next protons at $\delta 2.84\left(\mathrm{H}-3_{\mathrm{ax}}\right)$ and $\delta 3.48\left(\mathrm{H}-3_{\mathrm{eq}}\right)$ which were attached to $\mathrm{C}-3$. The long range correlation of H-6 and H-8 to carbon atoms at $\delta 95.66$ and $\delta$ 164.10 enabled these to be assigned as C-8 and $\mathrm{C}-5$, respectively. Weak correlation from the carbon signal at $\delta 79.44(\mathrm{C}-2)$ to protons $\mathrm{H}-2^{\prime}$ and $\mathrm{H}-6^{\prime}$ in the unsubstituted benzene ring clearly shared that the phenyl ring was bound to C-2.

From the above data, the structure of compound 1 was determined to be 5-hydroxy-7 methoxy flavanone (pinostrobin) (Fig. 1). The spectral data of 1 were consistent with those of pinostrobin reported elsewhere (Ichino et al., 1988; Gonzales et al., 1989).<smiles>COc1cc(O)c2c(c1)OC(c1ccccc1)CC2=O</smiles>

Fig. 1. Structure of pinostrobin (1). 


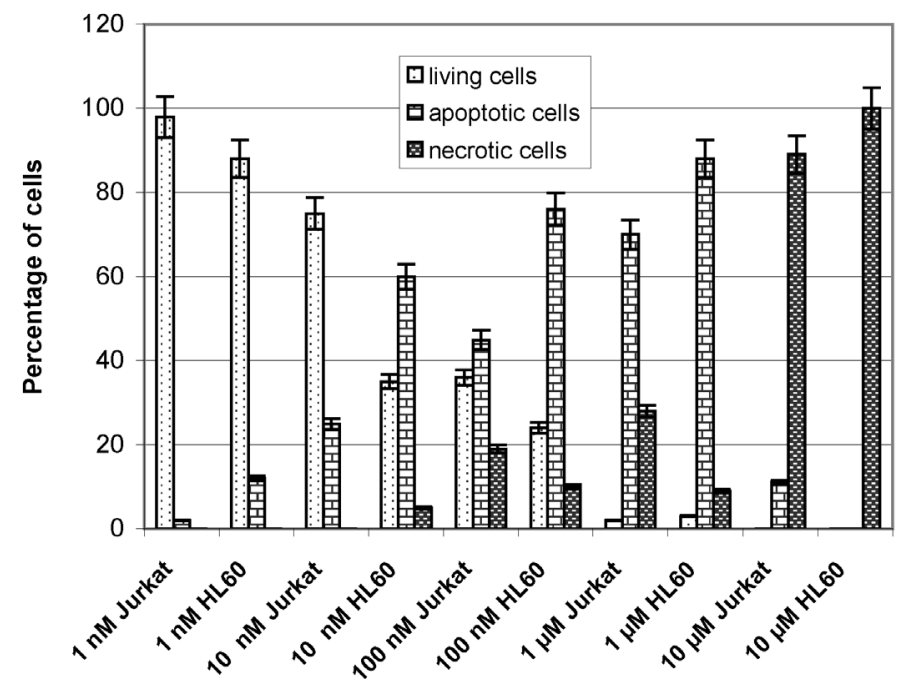

Fig. 2. Apoptotic, living and necrotic Jurkat and HL60 cells (24-h culture) after pinostrobin stimulation.

\section{Induction of apoptosis by pinostrobin}

Apoptosis or cell suicide is essential for normal lymphocyte development and homeostasis in the immune system (Rathmell and Thompson, 2002). Cells undergoing apoptosis show characteristic changes such as nuclear condensation, DNA fragmentation and translocation of PS to the outer leaflets of the plasma membrane (Martin et al., 1995). Apoptosis is one way of controlling immune responses and a variety of immunosuppressive drugs suppress harmful immune responses by inducing apoptosis of lymphocytes.

We measured apoptosis in two lines of human leukemic cells stimulated in vitro with various concentrations of pinostrobin. The influence of pinostrobin stimulation on the apoptosis process in leukemic cells cultures is presented in Fig. 2. As shown, the presence of apoptotic cells was observed after $24 \mathrm{~h}$ at $1 \mathrm{~nm}$ pinostrobin concentration. This effect is stronger in the HL60 cell line. The number of apoptotic cells increased with the concentration of pinostrobin: in the Jurkat cell line $10 \mathrm{~nm}-25 \%, 100 \mathrm{~nm}-45 \%$ and $1 \mu \mathrm{M}-70 \%$; in the HL60 cell line $10 \mathrm{~nm}-60 \%, 100 \mathrm{~nm}-76 \%$ and $1 \mu \mathrm{M}-88 \%$. Necrotic cells (toxic effect of pinostrobin) were observed in Jurkat and HL60 cell lines in concentrations of this compound $\geq 10 \mu \mathrm{M}$. As was shown, pinostrobin demonstrated a more intensive apoptotic response in stimulating the HL60 cell line. The percentage of apoptotic cells in controls was lower than $5 \%$.

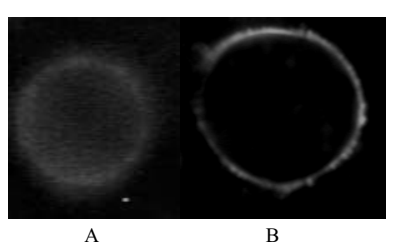

Fig. 3. The pinostrobin stimulated cells in the first phase of apoptosis - green fluorescence (in the present blackand-white pictures the fluorescence is gray) visualized by annexin V test; (A) Jurkat cell; (B) HL60 cell. Magnification 600 times.

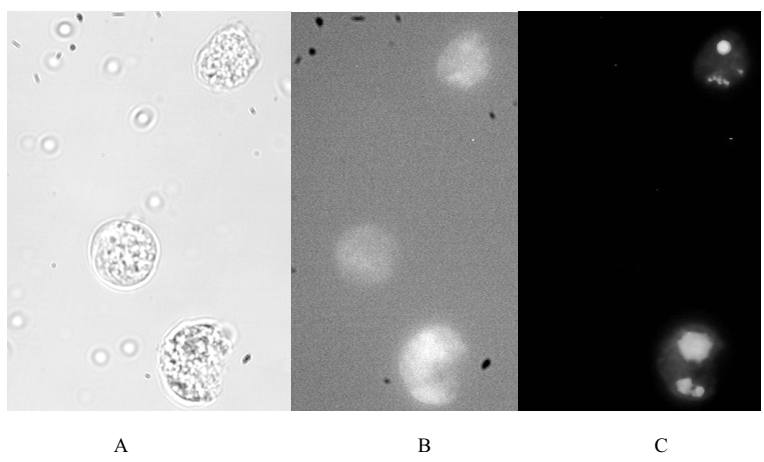

Fig. 4. (A) Natural fluorescence of pinostrobin in Jurkat cells (100 nM, 24-h culture). (B) The same cells in light microscope. (C) The same two Jurkat cells stimulated with pinostrobin in the late phase of apoptosis - green fluorescence (in the present black-and-white picture the fluorescence is gray) and red fluorescence (in the picture the fluorescence is white) - visualized by annexin V test. One living cell is invisible by this assay (magnification 600 times). 
The morphological features of cells and annexin $\mathrm{V}$ evaluation of the apoptotic response following the stimulation of cells is presented in Figs. 3 and 4. Pinostrobin quickly penetrates via cytoplasm to the cellular nucleus of cultured cells. The rapidity of penetration is dependent on the concentration of the compound and it is similar for Jurkat and HL60 cell lines. $1 \mathrm{~nm}$ solution of pinostrobin penetrates cells within $24 \mathrm{~h}$. The penetration time for

Cuong N.-M., Kamperdick C., Sung T.-V., and Adam G. (1996), Flavonoids from Caraya tonkinensis. Pharmazie 51, 128-131.

Gonzales A.-G., Aguiar Z.-E., Luis J.-G., Ravelo A.-G., Vazquez J.-T., and Dominquez X.-A. (1989), Flavonoids from Salvia texana. Phytochemistry 28, 2871-2872.

Harborne J.-B. (1999), The Flavonoids. Advances in Research since 1986. Chapman \& Hall/CRC, Boca Raton, London, New York, Washington, D.C.

Ichino K., Tanaka H., and Ito K. (1988), Two novel flavonoids from the leaves of Lindera umbellata var. lancae and L. umbellata. Tetrahedron 44, 3251-3259.

Kerry N. and Rice-Evans C. (1999), Inhibition of peroxynitrite-mediated oxidation of dopamine by flavonoid and phenolic antioxidants and their structural relationships. J. Neurochem. 73, 247-253.

Kuroyanagi M. and Fukushima S. (1982), Highly oxygenated flavonoids from Polygonum orientale. Chem. Pharm. Bull. 30, 1163-1168.

Le Bail J.-C., Aubourg L., and Habrioux G. (2000), Effect of pinostrobin on estrogen metabolism and estrogen receptor transactivation. Cancer Lett. 156, 37-44.

Martin S.-J., Reutelngsperger C.-P., Mc Gahon A.-J., Rader J.-A., van Schie R.-C., LaFace D.-M., and Green D.-R. (1995), Early redistribution of plasma membrane phosphatidylserine is a general feature of apoptosis regardless of the initiating stimulus inhibition by overexpression of Bcl-2 and Abl. J. Exp. Med. 182, 1545-1549.
$10 \mathrm{~nm}$ solution is $6 \mathrm{~h}$ whereas it takes only $2 \mathrm{~h}$ to penetrate cells for a $100 \mathrm{~nm}$ solution of this compound.

\section{Acknowledgements}

This work was supported by grant No 2 P05F 04928 from the State Committee for Scientific Research (KBN Poland).

Mata R., Rojas A., Acevedo L., Estrada S., Calzada F., Rojas I., Bye R., and Linares E. (1997), Smooth muscle relaxing flavonoids and terpenoids from Conyza filagionides. Planta Med. 63, 31-35.

Meragelman K.-M., McKee T.-C., and Boyd M.-R. (2001), Anti-HIV prenylated flavonoids from Montes africanus. J. Nat. Prod. 64, 546-548.

Rapta P., Misik V., Stasko A., and Vrabel I. (1995), Redox intermediates of flavonoids and caffeic acids esters from propolis: an EPR spectroscopy and cyclic voltammetry study. Free Radic Biol. Med. 18, 901908.

Rathmell I.-C. and Thompson C.-B. (2002), Pathways of apoptosis in lymphocyte development, homeostasis and disease. Cell 109, Suppl., S97-107.

Sukardiman, Darwanto A., Tanjung M., and Darmadi M.-O. (2000), Cytotoxic mechanism of flavonoid from Temu Kunci (Kaempferia pandurata) in cell culture of human mammary carcinoma. Clin. Hemorheol. Microcirculation 23, 185-190.

Takeara R., Albuquerque S., Lopes N.-P., and Lopes J.L.-C. (2003), Trypanocidal activity of Lychnophora staavioides Mart. (Veronieae, Asteraceae). Phytomedicine 10, 490-493.

Zava D.-T. and Duwe G. (1997), Estrogenic and antiproliferative properties of genistein and other flavonoids in human breast cancer cells in vitro. Nutr. Cancer 27, $31-40$. 